\title{
Supporting Social Enterprises to Support Vulnerable Consumers: The Example of Community Development Finance Institutions and Financial Exclusion
}

\section{Dr Therese Wilson *}

\begin{abstract}
This article examines the role of social enterprises in providing fair services to vulnerable consumers, focusing on the vulnerability of low income consumers to high cost exploitative credit as a result of a lack of access to mainstream financial services. It will be argued that both the state and the corporate sector have a role to play in providing the means with which vulnerable consumers can overcome financial exclusion, through access to fair services. However, this cannot and should not be achieved through increased welfare provision or through reliance on corporate social responsibility initiatives alone. In rejecting solutions focused on increased welfare or voluntary corporate social responsibility initiatives, this article suggests that regulatory support for the development and growth of social enterprises, such as community development finance institutions, will most effectively give rise to a social framework in which vulnerability and unequal opportunity with respect to financial services is addressed.
\end{abstract}

\section{Key words}

social enterprise, community development finance institutions, financial exclusion

\section{Introduction}

This article examines the role of social enterprises in providing fair services to vulnerable consumers, focusing on the vulnerability of low income consumers to high cost exploitative credit as a result of a lack of access to mainstream financial services.

\footnotetext{
Dr Therese Wilson is a Senior Lecturer at Griffith Law School and a member of the Socio-Legal Research Centre at Griffith University, Brisbane, Australia. The author wishes to thank the anonymous referees for their most helpful comments.
} 
In this article, the concept of vulnerability and its relationship to financial exclusion will first be explored, as will the role that the state has to play in addressing vulnerability, including by providing the means with which vulnerable consumers can overcome financial exclusion through access to fair services.

Financial exclusion cannot and should not be overcome through increased welfare provision. The reasons for this are two-fold: first, the welfare state has grown as far as it is likely to grow in western liberal democracies while still retaining popular and political support; and second, the 'hand up' rather than the 'hand out' approach is a preferable one in the area of financial services, as it brings with it a dignity inherent in true equality of opportunity, which is not a feature of welfare provision.

Financial exclusion cannot and should not be achieved through reliance on corporate social responsibility initiatives alone. There are limitations to what can be achieved under the dominant "business case" model of voluntary corporate social responsibility, and also dangers in seeking to regulate to compel activity in ways which are contrary to the inherent natures and values of the regulatee corporate entities. This does not mean, however, that there is no place for legislation to compel some degree of engagement with the issue of financial exclusion by banking corporations.

An alternative approach to increased welfare provision or reliance on corporate social responsibility initiatives, involves harnessing the ability of social enterprises to achieve social purposes. Social enterprises are organisations whose sole purpose for existence is the furtherance of a social purpose. Community development finance institutions are an example of a social enterprise, which exist to address financial exclusion in its various forms. State regulation to address financial exclusion through the use of community development finance institutions is potentially very simple, involving the subsidisation of the ongoing activities of these organisations. While this might in itself be regarded as a form of welfare in the sense that it involves government funding, it is notable that the investing state benefits from the enterprise's earned income which augments that investment, thus achieving the provision of more social services for each dollar invested. 
The article will conclude by arguing that issues confronting vulnerable consumers, at least in the area of financial exclusion and quite possibly beyond that, may best be addressed by a regulatory focus on supporting the growth and development of social enterprises.

\section{Vulnerability and financial exclusion}

What is financial exclusion?

The term 'financial exclusion' has been in use in the United Kingdom since at least the mid-1990s, and referred to a lack of access to the mainstream financial system, which includes banks, building societies and credit unions. According to research undertaken in the U.K. in 1999, seven per cent of British households had no access to mainstream financial products at all (such as transaction accounts and credit products) and 29 per cent of British households lacked access to mainstream credit. Those who lacked access to credit fell into two main groups: those with poor credit histories and those living on low incomes. It was found that those living on low incomes were likely to turn to alternative or 'fringe' credit providers to meet their credit needs. (Kempson 2000, p. 42)

Recent Australian research found that 15.6 per cent of the adult population in Australia were either fully excluded or severely excluded from financial services in 2010, where fully excluded Australians had no transaction account, credit facility or basic insurance, and where severely excluded Australians had only one of these products. Most of the severely excluded lacked access to credit, and 54.5 per cent of the fully or severely excluded could not raise \$3000 in an emergency. (Connolly et al. 2011, pp. 4, 8, 27)

The definition originally given to financial exclusion in the U.K. was: "those processes that prevent poor and disadvantaged social groups from gaining access to the financial system.”(Leyshon and Thrift 1995)

A report commissioned in 2004 provided as a 'working definition' of financial exclusion in Australia, "the lack of access by certain consumers to appropriate low cost, fair and safe financial products and services from mainstream providers.”(Chant Link and Associates 2004, p. 58) This definition is interesting for emphasising the 
appropriateness and fairness of the products on offer, and by including reference to mainstream providers as being the ones to provide these appropriate and fair products. This ignores the possibility of non-mainstream, but non-exploitative service providers, however the definition undoubtedly seeks to exclude access to exploitative high cost providers rather than, for example, access to low interest and no interest loans provided by community sector organisations or community development finance institutions ('CDFIs').

A concern with appropriateness of products is also incorporated in the European Commission definition of financial exclusion:

“A process whereby people encounter difficulties accessing and/or using financial services and products in the mainstream market that are appropriate to their needs and enable them to lead a normal social life in the society in which they belong.”(European Commission 2008, p. 9)

The European definition takes into account the context in which people live, which will be relevant in determining whether access to a financial product such as credit leads to financial and social exclusion. In a western liberal economy, for example, a lack of access to credit to purchase a personal computer on which a child can type his or her homework assignments will amount to financial exclusion and consequential social exclusion in that the child will be unable to lead a "normal" life in the context in which he or she lives. Conversely, access to sufficient credit to purchase a computer in a developing economy where very few people own computers would not amount to financial exclusion giving rise to social exclusion, as it would not prevent a person from living what is regarded as a "normal” life in that context.

The vulnerability inherent in financial exclusion.

Those who are financially excluded in a western liberal context are vulnerable to financial pressures including over-indebtedness and increased costs of living; and to social exclusion. 
In terms of financial pressures, the European Commission has noted that when a borrower is unable to access appropriate credit, negative socio-economic consequences follow, and that over-indebtedness can arise as a consequence of financial exclusion. (European Commission 2008, pp. 52, 53) In the absence of family or friend networks through which necessary credit can be obtained, financially excluded individuals will need to pay a high cost for credit, ${ }^{1}$ thus exacerbating their debt positions.

Increased costs of living can arise, for example, from having faulty or no whitegoods or car. One empirical study referred to the financial pressures that arose as a result of low income earners having to throw out food because of a faulty refrigerator, incurring laundromat costs because of an inability to buy a washing machine, or having increased petrol and repair costs because of an old and unreliable car. (AyresWearne and Palafox 2005, p. 18)

The link between financial and social exclusion was noted by Leyshon and Thrift, in that:

"Without access [to credit], the conduct of everyday life within a contemporary capitalist society can become extremely problematic.”(Leyshon and Thrift 1995, p. 313)

Ramsay observes that:

"Differing patterns of credit use and access to credit may act as a potential 'multiplier' of advantage and disadvantage in society potentially heightening social divisions...Exclusion from access to credit may therefore mean both economic exclusion from markets... and also exclusion from a central aspect of public expression in modern society.”(Ramsay 1995, p. 181)

I have referred above to an example of financial exclusion leading to an inability to purchase a computer, leading to social exclusion in the form of a child being unable to

${ }^{1}$ Interest rates of between 114 and 3380 per cent per annum have been found to apply to fringe credit products in an Australian study. See Howell, N et al. (2008), p. 39. 
complete homework assignments. Financial and social exclusion through lacking suitable clothing or transport to attend a job interview have also been noted:

“Inability to obtain credit in a tight cash week can result in no attendance at a range of functions, lack of personal loan can jeopardise a job interview (no suitable clothes or no transport) thus perpetuating low income and poverty, resulting in social exclusion.”(Chant Link and Associates 2004, p. 94)

Empirical research has highlighted some of the broader social consequences of not being able to access affordable credit to purchase essential household goods. These include health problems from "not sleeping, constantly tired; raw hands from washing clothes by hand; too tired to do things with the children"; family tensions from "harassing kids not to get their clothes dirty" and from having to spend time "buying fresh food every day"; and social isolation due to "feeling out of it or a lack of belonging because the family doesn't have a DVD, TV or computer, embarrassment as children feel they are not the same as their friends.”(Ayres-Wearne and Palafox 2005, p. 18)

Responding to vulnerability

It is necessary and appropriate that the state respond to the vulnerability arising out of financial exclusion, by regulating to achieve financial inclusion. Financial inclusion, for example through access to safe and affordable credit, has been shown to have social benefits extending beyond the meeting of an immediate need. These include educational and health benefits, (Barr 2005, p. 280) the development of financial skills including budgeting skills, improved family relationships and social inclusion for example through an ability to participate in local clubs and associations and training programs.(Ayres-Wearne and Palafox 2005, p. 36) This will clearly have broader economic impacts including fewer burdens on public health and legal systems. There are clearly pragmatic reasons for the state to take an interest in addressing the problem of financial exclusion.

The obligation to address financial exclusion also arises under an argument that "the state is constituted for the general and common benefit, not for a select few" and that 
it should be responsive to "vulnerability," as opposed to a more limited response to “discrimination.” (Fineman 2010, pp.28-31, 39) If one cannot access safe and affordable credit or, perhaps, a basic insurance product, one might be financially vulnerable to suffering over indebtedness and hardship in ways described above.(Arashiro 2011, pp. 40-42) Therefore the state has a role in ensuring the provision of resources that give people resilience against vulnerability and links this argument to one of achieving 'equality of opportunity':

"True equality of opportunity carries with it the obligation on the state to ensure access to the societal institutions that distribute social goods, such as wealth, health, employment, or security is generally open to all and that the opportunities these institutions provide are evenly distributed so that no person or groups of persons are unduly privileged while others are disadvantaged to the extent that they can be said to have few or no opportunities.”(Fineman 2010, p. 11)

This argument lends itself to a call for an "even” distribution of safe, fair and affordable financial products including credit, so as not to unduly disadvantage those people currently excluded from access to those products. It may be preferable to refer to a "fair” rather than "even” distribution, lest the latter term be confused with 'equal'. There is no "intrinsic value" in distributional equality as opposed to fairness. (Raz 2008, pp 1, 6) One needs to focus on the distribution which will address a problem, rather than achieving an equal distribution for the sake of it. It is not suggested that every member of society must have access to financial products such as credit in equal amounts on completely equal or identical terms. Rather it is suggested that a distribution of financial services and products such as will resolve the problem of financial exclusion, should be pursued.

The "vulnerability” argument is similar to an "equality of opportunity" argument. (Jacobs 2004) Lack of opportunity can be linked to social inequalities, which are arguably socially constructed. There is the "possibility that with different social institutions and practices, the relevant social inequalities might not exist...inequalities have their origins in the design of social circumstances.” (Jacobs 2004, p. 61) The significance of an understanding that inequalities are socially constructed is that 
socially constructed inequalities can be addressed through regulating to alter the relevant social framework.

The remainder of this paper will address the question of how best to alter the relevant social framework in order to meet the needs of vulnerable, financially excluded consumers. It will reject solutions based around increased welfare or voluntary corporate social responsibility initiatives, and will suggest that regulatory support for the development and growth of CDFIs, a form of social enterprise, will most effectively give rise to a social framework in which vulnerability and unequal opportunity with respect to financial services is addressed.

\section{The limitations of reliance on a welfare response}

Welfare at its limits

Pierson describes a political movement in recent years which has sought to find ways of assisting people "beyond the welfare state.” Rather than looking to increase welfare, regulators in western liberal democracies are looking to better regulate the market to make the market a "fairer" place. (Pierson 2006)

Most prominent in this debate are advocates of a "third way.” Pierson suggests an approach sitting somewhere between the "market-led neo-liberalism of Margaret Thatcher" and the "passive welfare state." where the welfare state is "enabling” rather than “providing." (Pierson 2006, p. 183)

This might be regarded as a necessary part of the evolution of the modern welfare state, where welfare provision itself is unlikely to grow further due to a lack of public and political support for such growth. As Pierson notes:

"The development of the welfare state was an integral part of the evolution of modern capitalist societies. However, the period of its remarkable growth was also historically unique. The welfare state has now 'grown to its limits.' Wholesale dismantling is neither necessary nor likely, but any further (costly) growth will begin to undermine the basis of its popular support.”(Pierson 2006, pp. 3-4) 
Being “enabling” rather than "providing” requires, for example, some focus on social inclusion, rather than just on addressing poverty. The "third way”, according to Pierson, means that "issues of social inequality should be addressed through equipping citizens with social capital, skills and education rather than through redistribution of resources.” (Pierson 2006, p. 237)

An "enabling" state would also provide a "hand up" through access to affordable credit, rather than simply a "hand out" through increased welfare, as the former approach is more likely to give rise to financial and social inclusion, and represent “equality of opportunity” with respect to financial services, as advocated by scholars such as Fineman (2010) and Jacobs (2004).

Furthering equality of opportunity through a "hand up" rather than a "hand out" By aiming to provide financial services to those denied access to them, one is furthering the cause of "equality of opportunity” and addressing financial vulnerability in a way that merely increasing welfare payments is not.

Jacobs proposes a model for ensuring equal opportunities in the allocation of resources that occurs through competitive processes. Jacobs asserts that this is to be done on a case by case basis, "focusing on particular institutions and practices and the opportunities they engender.” (Jacobs 2004, p. 23) In doing so, one must strive to achieve procedural fairness, which is fairness surrounding the rules and regulations governing the particular competition; stakes fairness which is fairness concerning the distribution of the resources at stake in the competition; and background fairness which takes into account the "initial starting positions or backgrounds" of those involved in the competition and regulates the competitive process "with a sensitivity to remedies for these inequalities.”(Jacobs 2004, pp. 16-17)

Jacobs' concept of stakes fairness is important for the purposes of this article, in that he maintains that the distribution of stakes in one competition should not impact upon the distribution of stakes in another. This means that the fact that a person has done badly in relation to the distribution of income and employment stakes, should not of 
itself make that person unworthy of consideration in the "credit stakes", at least not where that person has capacity to repay a loan without hardship. ${ }^{2}$ There is currently a lack of stakes fairness in vulnerable, low income consumers' lack of access to financial products such as credit, in that those on low incomes do not receive a fair distribution of available credit which is directed towards more "profitable" consumers. ${ }^{3}$ Vulnerable, low income consumers are being negatively impacted upon in the competition for credit, as a consequence of their having received less in the distribution of income and employment stakes.

Background and procedural fairness also require this economic discrimination to be overcome. The current allocation of access to financial products such as credit exhibits a lack of background fairness, where the market is constructed to exclude those living on lower incomes. There is also a lack of procedural fairness in terms of the rules governing the competition, which allow judgments about suitability for credit to be based on profitability concerns and, arguably, misguided concerns as to the risk of lending in the low income market.

Lack of access to credit cannot be addressed through increased welfare or charitable "handouts." Neither of those avenues offer the dignity or social benefits offered by financial inclusion, and they deny the equality of opportunity referred to by Jacobs while cementing socially constructed inequality. Jacobs makes some interesting observations concerning “welfare to work” programs as opposed to simply “welfare,” which can also provide some insights into the benefits of access to credit. He endorses welfare to work programs which require some sort of work or job training to be undertaken by those in receipt of unemployment benefits, as this requires "stakes fairness," in terms of a fair distribution of opportunities for work, to be taken

\footnotetext{
${ }^{2}$ Anecdotal evidence arising out of low interest and no interest loans programs in Australia supports the view that low income consumers can indeed repay loans and are not inherently 'risky' by virtue only of their income levels. See Scutella and Sheehan (2006); Ayres-Wearne and Palafox (2005). Note also that the average loan default rate in the ANZ's and Brotherhood of St Laurence's Progress Loan was 1.2 per cent, far lower than the average 'mainstream' personal loan default rate of approximately 5 per cent: Vawser and Associates (2009).

${ }^{3}$ As Ramsay (2005, p. 5) has noted: "Banks, notwithstanding their public relations efforts, are not strongly committed to cultivating lower income clients or branches which serve lower income areas which do not generate sufficient profits in this age of shareholder-driven capitalism.”
} 
seriously. He notes that those endorsing an "egalitarian position" would be critical of his endorsement of "welfare to work" but states, in relation to his position and that of egalitarians, that:

"The common ground we share is that work is really important to the lives of individuals in our society; this may be a contingent feature of our society, but it is nevertheless an undeniable one. To be excluded in our society from work is therefore unfair, even if excluded individuals are given cash payments that approach what they would have earned holding a job.” (Jacobs 2004, pp. 165166)

Jacobs refers to the right to employment and makes it clear that his endorsement of such programs relates to their fulfilment of the right to employment, rather than the imposition of duties on welfare recipients to work. (Jacobs 2004, p. 166)

Without endorsing or criticising welfare to work programs, an analogy can be drawn between these programs and programs to facilitate access to credit as opposed to simply increasing welfare payments. Programs which facilitate access to credit actually address a right to access safe and affordable credit, in the same way that a well constructed welfare to work program might address a right to work.

The World Bank has referred to "the lack of access to finance as a critical mechanism for generating persistent income inequality.” (World Bank 2008, p. ix) Such inequality can only be overcome by addressing that lack of access. Similarly, the U.K. government and its Social Investment Task Force has recognised the importance of looking "beyond welfare” to improve access to financial services in order to assist disadvantaged individuals and communities.(Social Investment Task Force 2005) This is reflective of Pierson's prediction of "a future in which welfare states focus on social investment rather than social costs. Welfare states should be enabling rather than providing, customized rather than generic, smaller but smarter.” (Pierson 2006, p.184)

Investment in social enterprises such as CDFIs is one way to enable rather than provide. Support for these organisations and their services will enable vulnerable 
consumers to become resilient against, and no longer vulnerable to, financial and social exclusion.

\section{The limitations of reliance on corporate social responsibility}

The dominant "business case" model

It might be argued that the regulatory focus should be on compelling banking corporations to address financial exclusion through providing safe, fair and affordable financial services to those currently financially excluded. There is a contrary argument which has attracted much support, that corporate social responsibility (“CSR”) should be a matter for the voluntary initiatives of corporations, in which external regulation should play no part. This was certainly the finding of two separate Australian government inquiries conducted in 2006. (Corporations and Markets Advisory Committee 2006; Parliamentary Joint Committee on Corporations and Financial Services 2006)

Both the Corporations and Markets Advisory Committee ("CAMAC") and the Parliamentary Joint Committee on Corporations and Financial Services ("PJCCFS”) reports found that any CSR initiatives should be voluntary. The PJCCFS accepted submissions made to it to the effect that CSR must remain a voluntary, not mandated, activity, primarily on the ground that "it is not possible to mandate good corporate behaviour.” (Parliamentary Joint Committee on Corporations and Financial Services 2006, pp. 35-36) The CAMAC report similarly found no need for any regulation to encourage or require CSR as corporations have sufficient basis to behave responsibly under a "business case":

“A well-managed company will generally see it as being in its own commercial interests, in terms of enhancing corporate value or opportunity, or managing risks to its business, to assess and, where appropriate, respond to the impact of its activities on the environment and social context in which it operates. Companies that fail to do that may jeopardise their commercial future.”(Corporations and Markets Advisory Committee 2006, p.78) 
The "business case” view of CSR is, according to Shamir (2004), an example of the “de-radicalization” of CSR through being “hijacked” by capitalist entities. Shamir notes that, as previously public roles have been taken over by private corporations, societal concerns regarding the conduct of corporations have increased, and corporations have had to respond to that. Shamir notes that "capitalists and capitalist entities do not sit still when faced with threats and challenges.”(Shamir 2004, p.670) Shamir refers to "various corporate strategies designed to prevent the use of law as means for bringing about greater corporate accountability,” and a process whereby "corporations have assertively embarked on the Social Responsibility bandwagon, gradually shaping the very notion of Social Responsibility in ways amenable to corporate concerns.” (Shamir 2004, pp 671, 676) As a result CSR has come to be regarded as a matter for voluntary initiative, concerned with furthering the strategic "business case” for corporations.

Bakan refers to this form of strategic CSR as being in essence a mask which corporations use to improve their reputations, and in a sense, hide their true, selfinterested natures.

\footnotetext{
"Corporate social responsibility is their new creed, a self-conscious corrective to earlier greed-inspired visions of the corporation. Despite this shift, the corporation itself has not changed. It remains, as it was at the time of its origins as a modern business institution in the middle of the nineteenth century, a legally designated 'person' designed to valorize self-interest and invalidate moral concern.” (Bakan 2004, p. 28)
}

The difficulty with leaving the provision of financial services to people on low incomes to voluntary initiatives by banks, propelled by such motivations as the business case, public relations and regulatory risk management, is that those initiatives, while commendable, are unlikely to go far enough in addressing financial exclusion. They are likely to be undertaken only to the extent that serves the public relations or risk management needs of the banking corporations involved. It is notable that in Australia only two of the major four Australian banks, and none of the smaller banks, have become voluntarily involved to any great extent in financial inclusion programs. This is notwithstanding the fact that financial exclusion and its 
consequential harms are arguably externalities arising out of the banking sector's choice to pursue what it has regarded as more "profitable" customers, and to not ensure access to safe, affordable and appropriate financial services for "less profitable” customers. This failure to respond by addressing negative externalities voluntarily might form the basis for regulatory intervention to compel such a response. (Johnston 2011)

The case for reflexively regulating for corporate support for social enterprise I argue that banking corporations have a key role to play in supporting CDFIs, and that that support should be mandated by legislation. The benefit of legal regulation is no doubt its strength and coercive force, where voluntary initiatives are not likely to achieve desired policy outcomes. Regulation by states through legislation enables the inclusion of “direct monetary incentive or disincentive effects” (McInerney 2004, p.29) which can have powerful regulatory consequences. Ideally, however, regulation should not quash positive voluntary initiatives nor evoke tokenistic responses from the regulated corporations. In proposing a regulatory response which will mandate corporate support for social enterprises (such as bank funding and support for CDFIs), three theoretical arguments concerning effective regulation will be drawn upon. The first of these suggests a regulatory model which supports a "corporate shared value” approach (Porter and Kramer 2011); the second recommends that regulators draw upon “pre-emptive self-regulation” by corporations (Solomon 2010); and the third advocates a reflexive approach to regulation, requiring responsiveness to existing social practice and attitudes. (Teubner 1983)

Porter and Kramer argue that corporations need to be encouraged to take a "shared value” approach, where business decisions are made on the basis of creating "shared value by reconceiving the intersection between society and corporate performance” and "identifying and expanding the connections between societal and economic progress.”(Porter and Kramer 2011, pp. 64, 66) An example might be an understanding by banking corporations that their own strength and prosperity relies on a strong economy and financially resilient members of the communities in which they operate. To achieve this, Porter and Kramer recommend a regulatory scheme that does not so much focus on "punishing” after the event corporations which have caused 
social and environmental harm, but instead encourages corporations to pursue shared value. The four characteristics of "shared value" regulation are stated to be:

(1) "sets clear and measurable social goals;

(2) sets performance standards but does not prescribe the methods to achieve them ;

(3) defined phase-in periods for meeting standards;

(4) puts in place universal measurements and performance reporting systems.” (Porter and Kramer 2011, p. 74)

Porter and Kramer contrast this with more prescriptive regulatory approaches as follows:

"Regulation that discourages shared value looks very different. It forces compliance with particular practices rather than focusing on measurable social improvement. It mandates a particular approach to meeting a standard blocking innovation and almost always inflicting cost on companies.” (Porter and Kramer 2011, p. 74)

Performance-based regulation such as that proposed by Porter and Kramer, might also draw on what Solomon refers to as 'pre-emptive self regulation' by corporations, comprised of any voluntary responses already taken by corporations to stave off external regulation. Solomon refers to a "new governance” where boundaries are blurred and regulated entities can themselves be involved in standard setting. What can then happen is that, through building on the already existing 'pre-emptive' regime:

"Policy-makers can create a new governance regulatory regime with the flexibility to adjust to problems as they arise, and with the necessary 'buy-in' from the private sector to encourage cooperation.”(Solomon 2010, p. 634)

In the case of securing the support of banking corporations for the financial inclusion programs conducted by CDFIs, voluntary initiatives undertaken by some banks to support existing financial inclusion programs could be drawn upon as models around 
which performance based standards could be set. Existing programs are therefore not disregarded or destroyed in the regulatory process, but are responded to appropriately.

Similarly, reflexive regulation requires "responsiveness" to existing social practice and attitudes. As Collins explains:

"Reflexive regulation tries to be sensitive to the ways in which the participants in a social practice think about their activity, with a view to producing regulatory outcomes that avoid as far as possible interventions that distort, devalue, or corrupt the social practice as it is viewed in its own socially grounded communication system.” (Collins 2004, p. 24)

Reflexive regulation is a concept arising out of Teubner's work around Luhmann's systems theory, (Luhmann 1982; Luhmann 1986) and cautions against seeking to regulate organisations in ways which disregard their internal norms and systems. Teubner asserts that regulation will fail if it is incompatible with the regulatee system, in that either the regulatee system will ignore it or fail to respond to it, or the regulatee system will respond to it but will be destroyed in the process. (Teubner 1986, p. 72) Therefore, rather than seeking to regulate an entity directly to mandate prescribed behaviour, it is better to establish structures and mechanisms that address the problem that gives rise to the regulatory response. Teubner states that:

"A reflexive orientation does not ask whether there are social problems to which the law must be responsive. Instead it seeks to identify opportunity structures that allow legal regulation to cope with social problems without, at the same time, irreversibly destroying valued patterns of social life.” (Teubner 1983, p.274)

Regulating so as to structure incentives and disincentives to which the regulated entities can respond consistently with their own natures and values, would be an example of reflexive regulation.

An example of performance-based, reflexive regulation that can draw on pre-emptive regulation in which regulatees are already engaged - as is the case with some 
Australian banks and financial inclusion programs - would be a model based on the U.S. Community Reinvestment Act 1977 (12 U.S.C. 2901) (“CRA”). The CRA rates banks on the extent of their lending to borrowers at different income levels, and the provision by them of community development loans. (Marsico 2006, pp535-536) A poor CRA rating can affect a bank's application for deposit-taking facilities including applications for mergers with and acquisitions of deposit-taking institutions. CRA ratings can also be taken into account in the approval process for opening or closing bank branches and banks must have a satisfactory CRA rating to be allowed to engage in extended financial activities such as insurance and securities. (Barr 2005, p. 105) Further, a bank's CRA rating can impact upon its reputation and is regarded as 'an important part of a bank’s public image.' (Taylor and Silver 2003, p. 181)

This is a performance-based model because the CRA relies on standards rather than rules, and regulatees have an opportunity to determine the manner in which they will meet those standards. (Barr 2005, p. 108) CRA standards permit the banks to respond to local needs based on their institutional organisation, market assessments and business plans, allowing:

“...banks to help shape the content of the standard in CRA's application to them, in their local context, during their CRA evaluation and merger applications...[which]increases the likelihood that the performance will be analysed according to the regulated entity's view of an appropriate standard for the institution.” (Barr 2005, pp. 183-184)

Based upon the U.S. experience where CDFIs have benefitted greatly from CRA investment, (Rubin 2008, p. 201; Dreier 2003, p. 193) a CRA-like ratings system would operate to encourage investment by banks in the CDFI sector thus assisting those institutions to effectively address financial exclusion.

It should be acknowledged that the CRA is not without its critics, and that it has been blamed by some commentators for the 2007 sub-prime mortgage crisis and the consequential 2008 global financial crisis. (Seidman 2008b) It is notable however that the CRA does not "encourage or condone bad lending” but rather requires "safe and sound lending practices.” (Seidman 2008b) It is important to distinguish between 
"legitimate sub-prime” lending on the one hand, which is simply responsible lending to people excluded from access to mainstream credit products, and which is encouraged under the CRA (Engel and McCoy 2002); and predatory lending on the other hand. Regulators introducing CRA-like legislation need to ensure that the model does not inadvertently encourage irresponsible lending practices.

\title{
The social enterprise model: community development finance institutions
}

What is a social enterprise and what is its advantage in social problem-solving?

There are various definitions of "social enterprise” including:

\begin{abstract}
“An organisation that is driven by particular social and community values, whilst aiming to operate effectively and sustainably within a competitive business framework i.e. helping the community as well as maintaining a viable business.” (Kerlin 2006, p. 250)
\end{abstract}

“Organisations that use nongovernmental, market-based approaches to address social issues...an increasingly popular means of funding and supplying social initiatives....”(Kerlin 2006, p. 247)

"Social enterprises- defined simply- are organisations seeking business solutions to social problems.” (Thompson and Doherty 2006, p. 362)

Essentially social enterprises are both not for profit and non-governmental, and generate some or all of their own funding through business enterprise. The profits resulting out of the business enterprise are not paid to business owners or shareholders, but rather are used to support the organisation's social purpose or mission. Social enterprises have alternatively been referred to as "social purpose organisations” which are "non profit organisations engaged in mission- supporting commercial activity.”(Kerlin 2006, p. 247) Unlike most business enterprises where support for social ends can generally only be justified on the basis of corporate social responsibility, in the case of social enterprises "social ends and profit motives do not 
contradict each other, but rather have complementary outcomes, and constitute a ‘double bottom line'.” (Cornelius et al 2008, p. 355)

This is about so much more than corporate social responsibility, in the sense that the social enterprise's whole reason for existence is its social purpose. Social enterprises constitute the "growing number of creative enterprises that focus on the public good as part and parcel of their business mission.”(Hightower and DeMarco 2008, p. 29)

Burkett and Drew (2008) identify four characteristics common to all social enterprises as follows:

- "Social objectives are core to the purposes and focus of the enterprise

- Limited distribution of profits... the majority of profits are reinvested in the enterprise and/or an associated social entity

- Mixture of capital inputs...the enterprise is supported through a mixture of grant income/ subsidised income and earned income

- Generation of a social return in addition to a financial return. The traditional not for profit on the other hand is a community sector organisation that relies on government, industry or philanthropic funding, and does not generate its own income to any significant extent.”

A key benefit of the social enterprise model is the ability to be less reliant on external sources of funding, and so less vulnerable to: (a) political changes, such as a change in government and in government policy; (b) a change to the CEO or board of directors of a corporation that had previously been sympathetic to and financially supportive of a particular organisation but which is no longer; or (c) a change in economic environment making philanthropic funds more difficult to source.

What is a CDFI and what does it need to survive?

A CDFI is a type of social enterprise whose social purpose or mission is to address financial exclusion. 
The Community Development Finance Association, which is the representative body for CDFIs in the U.K., defines CDFIs as follows:

“CDFIs are independent financial institutions that provide finance and support to help individuals and organisations develop and create wealth in disadvantaged communities or under-served markets. Community development finance delivers innovative financial products primarily aimed at entrepreneurs in disadvantaged areas, but also addressing increasing personal debt in poorer communities.”(Community Development Finance Association 2008,p. 1)

Much of the lending undertaken by CDFIs is microenterprise, or business, lending; however, many CDFIs also engage in personal microfinance. A CDFI pilot which has recently been announced by the Australian government and which is designed to foster the development and growth of a CDFI industry in Australia has focused on personal lending to financially excluded individuals. (Department of FAHCSIA, 2011)

A key difference between no interest and low interest loan programs conducted by community sector organisations, and the provision of microfinance by CDFIs, is that the CDFI model is arguably likely to be more sustainable, in the sense of financially self-sustaining while making a positive social impact. One Australian bank has referred to sustainability of microfinance programs as a "major challenge”:

“A major challenge for microfinance development in Australia is 'sustainability' of the programs. In this context sustainability is about ensuring the continuity of services and programs that make a positive and ongoing contribution to addressing financial exclusion- both financially and socially.” (NAB 2010)

There are contradictory views as to the ability of CDFIs to make microfinance activities in developed countries fully self-sustaining without external support. It may be that financially sustainable microfinance models in developed economies will not be possible, except through some external subsidisation. Certainly the difficulties 
faced by Shorebank Corporation in the U.S. does suggest a need for ongoing government and industry investment to ensure that CDFIs can continue to meet their social purpose of addressing financial exclusion.

Shorebank Corporation was, until recently, an example of a highly successful CDFI in the U.S., operating as a community development bank. A small part of its activities included personal microfinance, as part of its community development credit activities. (Shorebank 2007) It had been actively involved in "rescue loans", refinancing mortgages for homeowners at risk due to predatory, subprime lending. (Shorebank 2007) Shorebank’s mission was “to provide well-designed, responsible credit and other financial products and services to lower income communities, businesses and consumers.”(Seidman 2008a) On 20 August 2010 Shorebank was closed by regulators, and has been purchased by a newly-chartered bank, Urban Partnership Bank. Urban Partnership Bank was chartered with significant capital injection from large financial institutions. (Zeilinski 2010)

The difficulties faced by Shorebank have been attributed in part to it "living its mission" and focusing on its social purpose. (Cohen 2010) Given that a strength of the CDFI model is the focus on achieving a social purpose rather than on pure profit maximisation, Shorebank's failure raises interesting questions about the ability of CDFIs to remain true to their social purpose while also remaining commercially viable, at least in the absence of some ongoing government and industry subsidisation. There are risks in requiring CDFIs to achieve full financial sustainability without the benefit of any subsidisation, as noted by Rubin:

“Adopting a 'business mindset' can be very difficult for a nonprofit...it can move a nonprofit organisation's activities away from its social mission and potentially even harm the individuals the organisation was created to serve.” (Rubin 2008, p. 192)

Certainly, the Community Development Finance Association in the U.K. expresses a strong view that government and industry support are essential for the ongoing viability of CDFIs. This is because of the work undertaken by personal lending CDFIs 
which involves not only the provision of responsible credit, but also money support and advice. The Association notes that:

"CDFI customers are relatively resource-intensive to serve, given that many often require extensive up-front and ongoing business or financial capability support and advice...CDFIs will rarely be in a position to meet all their capital and revenue requirements purely from their lending activity.” (Community Development Finance Association 2010, p. 12)

It is this additional support and advice which means that CDFIs are well placed to provide the 'appropriate to needs' credit products referred to in the European definition of financial exclusion, discussed above. It should therefore not be deviated from in a quest for financial self-sustainability.

The experience in the U.K. has been that CDFIs apply their earned income - which has increased from 25 per cent of their income in 2008/ 2009 to 40 per cent of their income in 2009/2010 - to funding operational costs. Support for operational costs is then augmented by government grant funding, and capital for onlending is sourced from a mix of government grants and investment income. (Community Development Finance Association 2010, p. 12) A significant source of funding for CDFIs in the UK has been the Department for Work and Pensions’ Financial Inclusion Growth Fund which has invested $£ 10$ million in the sector since 2005. (Community Development Finance Association 2010, p. 33) Private investment has been encouraged by the Community Investment Tax Relief Scheme which provides 25 per cent tax relief on investment on CDFIs, spread over a five year period. That scheme has raised $£ 63$ million in investment funds for CDFIs since 2007. (Community Development Finance Association 2010, p. 13)

Similarly, in the U.S., as described above, the Community Reinvestment Act has encouraged investment in the CDFI sector there. CDFIs in the U.S. also enjoy the benefit of a CDFI fund and the New Markets Tax Credit administered by that fund, which encourages investment in 'community development entities' that in turn invest in 'qualified low-income community investments.' The fund itself was established in 19994 using federal government resources to enable investment in CDFIs providing 
financial services to under-served people and communities. (House of Commons Treasury Committee 2005-6, p. 23) The CDFI fund also offers tax credits to 'community development entities' who can in turn offer those tax credits to investors who invest in them. (Seidman 2008a) Those investors receive a tax credit representing 39 per cent of the cost of the investment claimed over a seven year period. Between 2003 and 2010 the CDFI fund allocated a total of U.S. \$29.5 billion in tax credits. (Community Development Financial Institutions Fund 2011) There is no doubt that CDFIs have been able to survive in the U.S. and the U.K. as a result of the significant funding available.

On the basis that some financial subsidisation from government and industry is likely to be necessary to enable the growth and continuation of a CDFI industry, then the provision of such subsidisation should be a key focus of regulators. Systems theory instructs that where systems are well-placed to contribute to regulatory solutions, the role of regulation may be simply to enable them to survive. Dunsire refers to this as “subsidisation,” likening government financial subsidy to energy inputs for biological organisms, keeping them alive. (Dunsire 1996, p. 309)

Support for CDFIs would be a highly effective regulatory response to financial exclusion. Dunsire explains subsidisation in the following terms:

"The key is to select a social actor or institution, often in the voluntary sector, which is already performing what the administrator regards as a public service, and simply ensure its metabolic survival. Its operations cannot be steered without danger to its self-reproduction processes and identity; but by helping its physical survival, the administrator is exerting a steering effect on broader society.” (Dunsire 1996, p. 320)

Dunsire's reference to not “steering” the institutions' operations arises out of his concern about destroying the nature of the institution and its ability to perform its role, by attaching conditions to financial subsidy.(Dunsire 1996, p. 309) At the very least, I would argue that in the case of social enterprises such as CDFIs, any conditions attached to financial support by government or industry should be 
respectfully negotiated with the recipient social enterprise to ensure compatibility of those conditions with the social enterprise’s social mission.

Regulators can achieve positive social impacts through recognising the potential of social enterprises to address social problems, provide them with financial support and regulate to compel or encourage industry to provide similar support. In the case of CDFIs and their capacity to address the problem of financial exclusion, I argue that the banking industry should be encouraged to support CDFIs through a performance based regulatory model such as the U.S. Community Reinvestment Act 1977.

\section{Conclusion}

Financial exclusion is an ongoing problem in western liberal economies. This is a societal problem which leaves people vulnerable to financial pressures and social exclusion. Drawing upon the work of Fineman and Jacobs I have argued that the inequality of access to financial products and services should be addressed by the state in such a way as to achieve equality of opportunity in relation to those products and services.

I have argued that increasing welfare payments to the financially excluded will not address the problem. It is unlikely that the welfare state can grow and still retain political and public support, and states need to find more creative and empowering ways of assisting those members of society who need assistance. I have referred here to the "third way", "hand up” not "hand out” approach. Assisting social enterprises to provide fair and appropriate services to those in need, with a view not to making a profit but rather to fulfilling a social purpose, amounts to a "beyond welfare” regulatory approach, designed to foster "equality of opportunity."

Voluntary corporate social responsibility initiatives undertaken in accordance with the "business case” model of CSR, will only go as far as is necessary to further corporations' strategic goals, for example through enhancing their reputations in the market. This is unlikely to resolve a problem such as financial exclusion. Financial exclusion can be regarded as a negative externality which has arisen as a result of the banking industry's decision to pursue more profitable customers and not ensure fair and adequate financial services for all members of society. However, this does not 
mean that mandating that banking corporations provide those services directly will be effective. The lessons of reflexive regulation suggest that attempts to compel banks to undertake activities that do not fit neatly with their inherent natures and values, such as direct lending to low income consumers, is likely to be ignored at least in the sense of eliciting tokenistic responses. Drawing on pre-emptive regulation undertaken by some banks which largely involves financial support for financial inclusion programs, banks can be encouraged to provide support for CDFIs working to address financial exclusion, through performance based regulation such as the U.S. Community Reinvestment Act 1977.

Community Development Finance Institutions are social enterprises that exist for the sole purpose of addressing financial exclusion in it various forms, including a lack of access to safe and affordable small amount credit (or "microfinance”) as experienced by some individuals. Regulators can harness the potential of these and other social enterprises to resolve societal problems, through providing financial support to them to enable their growth and survival, and by encouraging or compelling industry to provide similar support. 


\section{Reference List}

Arashiro, Z. (2011). Money Matters in Times of Change: Financial Vulnerability through the Life Course. Melbourne: Brotherhood of St Laurence.

Ayres-Wearne, V., Palafox, J. (2005). NILS. Small Loans- Big Changes. Melbourne: Good Shepherd Youth and Family Service.

Bakan, J. (2004) The Corporation: The Pathological Pursuit of Profit and Power. London: Constable and Robinson.

Barr, M. (2005) Microfinance and Financial Development. Michigan Journal of International Law, 26, 271-296.

Barr, M. (2005) Credit Where It Counts: The Community Reinvestment Act and its Critics. New York University Law Review,75, 101-233.

Burkett, I., Drew, B. (2008) Financial Inclusion, Market Failures and New Markets: Possibilities for Community Development Finance Institutions in Australia. Brisbane: Foresters Community Finance Limited.

Chant Link and Associates. (2004). A Report on Financial Exclusion in Australia. Melbourne:ANZ.

Cohen, R. (2010) Understanding Shorebank: A Community Development Bank Passes. http://3blmedia.com/theCSRfeed/Understanding-Shorebank viewed 11 October 2010.

Collins, H. (2004) Regulating Contract Law. In Christine Parker et al (eds) Regulating Law (pp 13- 32).

Community Development Finance Association. (2008) Annual Review: Building Community Development Finance London: Community Development Finance Association.

Community Development Finance Association. (2010) Inside Out 2010: The State of Community Development Finance. http://www.cdfa.org.uk/wp-content/uploads/2010/12/InsideOut-20101.pdf viewed 28 September 2011.

Community Development Financial Institutions Fund (2011) New Markets Tax Credit Program. http://www.cdfifund.gov/what_we_do/programs_id.asp?programid=5 viewed 28 September 2011.

Connolly, C et al. (2011) Measuring Financial Exclusion in Australia Sydney:The Centre for Social Impact.

Cornelius, N. et al. (2008) Corporate Social Responsibility and the Social Enterprise Journal of Business Ethics, 81, 355-370. 
Corporations and Markets Advisory Committee. (2006) The Social Responsibility of Corporations. Sydney: Corporations and Markets Advisory Committee, Australian Government.

Department of FAHCSIA. (2011). Community Development Finance Institutions (CDFI) Pilot Project.

http://www.fahcsia.gov.au/sa/communities/progserv/financial_management_program/ Pages/cdfi.aspx , viewed 18 February 2011.

Dreier, P. (2003). Protest, Progress, and the Politics of Reinvestment. In Squires, G. (Ed.), Organising Access to Capital. Advocacy and the Democratisation of Financial Institutions (pp 188- 220). Philadelphia: Temple University Press.

Dunsire, A. (1996) Tipping the Balance: Autopoiesis and Governance.

Administration and Society, 29 (3), 299- 334.

Engel, K., McCoy, P (2002). The CRA Implications of Predatory Lending. Fordham Urban Law Journal, 29, 1571 - 1600.

European Commission. (2008). Financial Services Provision and Prevention of Financial Exclusion. Brussels: European Commission, Directorate-General for Employment, Social Affairs and Equal Opportunities.

Fineman, M. (2010). The Vulnerable Subject and the Responsive State. Emory University School of Law, Research Paper No 10-130, http://ssrn.com/abstract=1694740, viewed 6 June 2011.

Hightower, J., DeMarco, S. (2008) Swim Against the Current: Even a Dead Fish Can Go With the Flow. New Jersey: John Wiley and Sons.

House of Commons Treasury Committee. (2005-6) Financial Inclusion: Credit, Savings, Advice and Insurance, Twelfth Report. London: House of Commons Treasury Committee.

Howell, N et al. (2008). Interest Rate Caps: Protection or Paternalism? Brisbane: Centre for Credit and Consumer Law.

Jacobs, L. (2004). Pursuing Equal Opportunities. Cambridge: Cambridge University Press.

Johnston, A. (2011) Facing Up To The Social Cost: The Real Meaning of Corporate Social Responsibility. Griffith Law Review20 (1), forthcoming.

Kempson, E. et al. (2000). In or Out? Financial Exclusion: A Literature and Research Review. London: Financial Services Authority.

Kerlin, J. (2006) Social Enterprise in the United States and Europe: Understanding and Learning from the Differences. Voluntas, 17, 247- 263. 
Leyshon, A., Thrift, N. (1995). Geographies of Financial Exclusion: Financial Abandonment in Britain and the United States. Transactions of the Institute of British Geographers 20 (3), 312-341.

Luhmann, N. (1982). The Differentiation of Society. New York: Columbia University Press.

Luhmann, N. (1986) The Self-Reproduction of Law and its Limits. In Teubner, G. (Ed.) Dilemmas of Law in the Welfare State. Berlin: Walter de Gruyter.

Marsico, R. (2006). The 2004-2005 Amendments to the Community Reinvestment Act Regulations: For Communities One Step Forward and Three Steps Back. Clearinghouse Review 39, 534- 545.

McInerney, T. (2004). Putting Regulation Before Responsibility: The Limits of Voluntary Corporate Social Responsibility Washington: Public Law and legal theory Working paper No 123, The George Washington University Law School.

Morgan, B., Yeung, K. (2007) An Introduction to Law and Regulation. New York: Cambridge University Press.

NAB. (2010). Do You Really Want to Hurt Me?: Exploring the Costs of Fringe Lending- a Report on the NAB Small Loans Pilot. Melbourne: NAB.

Parliamentary Joint Committee on Corporations and Financial Services. (2006). Corporate Responsibility: Managing Risk and Creating Value. Canberra:

Commonwealth of Australia.

Pierson, C. (2006). Beyond the Welfare State: The New Political Economy of Welfare. Cambridge: Polity Press.

Porter, M., Kramer, M. (2011) Creating Shared Value: How to Reinvent CapitalismAnd Unleash a Wave of Innovation and Growth. Harvard Business Review, JanuaryFebruary, http://hbr.org/2011/01/the-big-idea-creating-shared-value/ar/1, viewed 16 March 2011.

Ramsay, I. (1995). Consumer Credit Law, Distributive Justice and the Welfare State. Oxford Journal of Legal Studies, 15, 177-197.

Ramsay, I. (2000). Access to Credit in the Alternative Consumer Credit Market. British Columbia: Office of Consumer Affairs, Industry Canada and Ministry of the Attorney General.

Raz, J. (2008). On the Value of Distributional Equality. Oxford: Research Paper No 41/2008, Oxford Legal Studies.

Scutella, R., Sheehan, G. (2006). To Their Credit: Learning About Personal Loans for People on Low Incomes. Brotherhood Comment , August, 10-11. 
Seidman, E. (2008a) The New Markets Tax Credit: A Valuable Tool for Economic Development. New York: Living Cities: The National Community Development Initiative.

Seidman, E. (2008b) No Larry, CRA Didn't Cause the Sub-Prime Mess. http://www.newamerica.net/blog/asset-building/2008/no-larry-cra-didn-t-cause-subprime-mess-3210 viewed 29 July 2008.

Shamir, R. (2004). The De-Radicalization of Corporate Social Responsibility. Critical Sociology, 30 (3), 669- 689.

Rubin, J. (2008). Adaptation or Extinction? Community Development Loan Funds at a Crossroads. Journal of Urban Affairs, 30 (2),191- 220.

Seidman, E. (2008). Testimony of Ellen Seidman, Director, Financial Services and Education Project. Washington DC: Paper presented at the Committee on Financial Services, United States House of Representatives.

Shorebank. (2007) Shorebank 2007 Annual Report. Chicago: Shorebank.

Social Investment Task Force. (2005). Enterprising Communities: Wealth Beyond Welfare. A 2005 Update on the Social Investment Task Force.' London: Social Investment Task Force.

Solomon, J. (2010). New Governance, Pre-emptive Self-Regulation, and the Blurring of Boundaries in Regulatory Theory and Practice. Wisconsin Law Review, 591- 625.

Taylor, J., Silver, J.(2003). The Essential Role of Activism in Community Reinvestment. In Gregory Squires (Ed.) Organising Access to Capital, Advocacy and Democratisation of Financial Institutions, 169 - 187. Philadelphia: Temple University Press.

Teubner, G. (1983). Substantive and Reflexive Elements in Modern Law. Law and Society Review, 17 (2), 239- $285 .$.

Teubner, G. (1986). Dilemmas of Law in the Welfare State. Berlin: Walter de Gruyter.

Thompson, J., Doherty, B. (2006) The Diverse World of Social Enterprise. International Journal of Social Economics, 33 (5/6), 361-375.

Vawser and Associates. (2009) Progress Loans: Towards Affordable Credit for Low Income Australians. Melbourne: ANZ, Brotherhood of St Laurence.

World Bank. (2008). Finance For All? Policies and Pitfalls in Expanding Access. Washington DC: The World Bank.

Zeilinski, B. (2010). Politically Connected Shorebank of Chicago Fails and Reincarnated at Taxpayer Expense. http://problembanklist.com/politically-connected- 
shorebank-of-chicago-fails-and-reincarnated-at-taxpayer-expense-0172 viewed 11 October 2010. 